\title{
Aproceros leucopoda (Hymenoptera: Argidae): An East Asian pest of elms (Ulmus spp.) invading Europe
}

\author{
Stephan M. BLANK ${ }^{1}$, Hideho HARA ${ }^{2}$, JózSEF MIKULÁS ${ }^{3}$, GyÖRgy CSÓKA ${ }^{4}$, ConSTANTIN CIORNEI ${ }^{5}$, Raoul \\ CONSTANTINEANU ${ }^{6}$, IRINEL CONSTANTINEANU ${ }^{6}$, LADISLAV ROLLER ${ }^{7}$, EwALD ALTENHOFER ${ }^{8}$, TOMASZ \\ HUFLEJT $^{9}$ and GÁBOR VÉTEK ${ }^{10}$
}

\author{
${ }^{1}$ Senckenberg Deutsches Entomologisches Institut, Eberswalder Str. 90, 15374 Müncheberg, Germany; \\ e-mail: sblank@senckenberg.de \\ ${ }^{2}$ Forestry Research Institute, Hokkaido Research Organization, Bibai, Hokkaido; Japan 079-0198; e-mail: hara-hideho@hro.or.jp \\ ${ }^{3}$ Corvinus University of Budapest, Research Institute for Viticulture and Enology, Urihegy 5/a, 6000 Kecskemét; Hungary, \\ e-mail: jozsef@mikulas.net \\ ${ }^{4}$ Forest Research Institute, Department of Forest Protection, P.O.Box 2, 3232 Mátrafüred, Hungary; e-mail: csokagy@erti.hu \\ ${ }^{5}$ Forest Research and Management Institute, Stefan Cel Mare Street 28, Bacau, Romania; e-mail: ciorneitinel@yahoo.com \\ ${ }^{6}$ Biological Research Institute, Lascar Catargi 47, 700107 Iaşi, Romania; e-mail: racon38@yahoo.com, \\ irinaconstantineanu@yahoo.com \\ ${ }^{7}$ Slovak Academy of Sciences, Institute of Zoology, Dúbravská cesta 9, 84506 Bratislava, Slovakia; e-mail: uzaeroll@savba.sk \\ ${ }^{8}$ Etzen 39, 3920 Groß Gerungs, Austria; e-mail: ealtenhofer@everymail.net \\ ${ }^{9}$ Polish Academy of Sciences, Museum and Institute of Zoology, Wilcza 64, 00-679 Warszawa, Poland; \\ e-mail: thuflejt@miiz.waw.pl \\ ${ }^{10}$ Corvinus University of Budapest, Faculty of Horticultural Science, Department of Entomology, Villanyi út 29-43, 1118 Budapest, \\ Hungary; e-mail: gabor.vetek@uni-corvinus.hu
}

Key words. Argidae, Aproceros leucopoda, sawfly, Ulmus, Europe, invasive species, pest species, identification, bionomy, dispersal, Dutch elm disease

\begin{abstract}
An invasive sawfly Aproceros leucopoda Takeuchi, 1939, which originates from East Asia, has colonized elms (Ulmus spp.) in Austria, Hungary, Poland, Romania, Slovakia and the Ukraine, at least since 2003. In Europe, the larvae can completely defoliate native and non-native elm trees and may cause at least partial dieback. Field observations indicate that elms are infested independent of their age and site characteristics. The life cycle of A. leucopoda is described based on material reared in Hokkaido, Japan. Parthenogenetic reproduction, short life cycle of summer generations and the ability to produce four generations per year result in the production of numerous progeny. The evolution of a seasonal dimorphism in head morphology, a simple cocoon that is attached directly to the host plant and a short period spent in the cocoon stage during summer, are putative apomorphies shared by Aproceros Takeuchi, 1939 and Aprosthema Konow, 1899. These traits reduce developmental costs and contribute to the proliferation of $A$. leucopoda. No specialized parasitoid, that can effectively reduce outbreaks of this species, is known. It is likely that this pest will spread into central and south-western Europe. Further monitoring of $A$. leucopoda is required to assess future range extensions in Europe, its exacerbating effect on Dutch elm disease and to find a suitable biocontrol agent. Concise keys to imaginal and larval stages are presented that will facilitate the identification of $A$. leucopoda.
\end{abstract}

\section{INTRODUCTION}

In Europe, introductions and invasions of non-native insect species have repeatedly attracted considerable attention due to the economic and aesthetic damage they cause. Recent examples are the horse chestnut leafminer Cameraria ohridella Deschka \& Dimic, 1986 (Lepidoptera: Gracillariidae) and the multicolored Asian lady beetle Harmonia axyridis (Pallas, 1773) (Coleoptera: Coccinellidae). Larval feeding by the former causes premature leaf fall and affects seed quantity in horse chestnut (Aesculus hippocastanum L.; Guichard \& Augustin, 2002; Thalmann et al., 2003). The latter was originally introduced as a biological control agent of aphids and coccids. It is now seen as a potential risk species as it is voracious and eats a wide range prey including many arthropods and even plants, besides the actual target pest species (van Lenteren et al., 2003, 2008; Brown et al., 2008).

Now, another invasive species has arrived in Europe, the East Asian sawfly Aproceros leucopoda Takeuchi, 1939, which causes outbreaks in south-eastern Europe and severely defoliates elms. At least since the late 1960s, the abundance of elm trees has dramatically declined in Europe due to Dutch elm disease. Three species of ascomycete microfungi, which are transmitted by bark beetles (Scolytidae), cause the affected host trees to wither and die (e.g., Holmes \& Heybroek, 1990; Smalley \& Guries, 1993). Only a small fraction of mature elms have survived this attack in Europe. For example, in many areas of central and southern Britain about $50-90 \%$ of elms are 
dead or show signs of dieback (Brasier, 1996). Phytophagous insects, like $A$. leucopoda, which reduce the area of leaves that is photosynthetically active, may further weaken trees affected by Dutch elm disease.

Aproceros leucopoda is member of the Argidae, a group of sawflies, of which there are almost 900 species worldwide and 68 in Europe (Taeger et al., 2006, Taeger $\&$ Blank, 2008). The generally free-feeding larvae are usually monophagous or associated with several closely related host species of angiosperms. The Arginae, one of the two European subfamilies of Argidae, include a number of destructive, multivoltine species. Wild and cultivated roses may be defoliated by larvae of Arge ochropus (Gmelin, 1790) and A. pagana (Panzer, 1797), and barberries by $A$. berberidis Schrank, 1802 (Scheibelreiter, 1973; Pschorn-Walcher, 1982; Taeger et al., 1998). Arge pullata (Zaddach, 1859), a species injurious to birch trees, may poison sheep, cattle and other animals if they ingest the larvae, which contain the liver toxin lophyrotomin (Brummerstedt et al., 1987; Thamsborg et al., 1987; Kannan et al., 1988). Most Sterictiphorinae, the other European group of Argidae, are rare and inconspicuous. Aproceros leucopoda is the first Sterictiphorinae species for which outbreaks and severe damage to the larval host trees is reported.

Here the occurrence of Aproceros leucopoda in Europe is reported for the first time. Data on its current distribution, range of larval host plants and the damage caused to elm stands are presented. The bionomy of A. leucopoda is described for a population recently studied in Japan. The identification keys can be used by specialists and nonspecialists to identify imagines and larvae. Finally, an attempt is made to assess the effect and future spread of this pest.

\section{MATERIAL AND METHODS}

Studies on the bionomics of Aproceros leucopoda were conducted by $\mathrm{H}$. Hara on two trees of Ulmus pumila (3-5 $\mathrm{m}$ high) at the Doto Branch of the Hokkaido Forestry Research Institute, Shintoku, Tokachi, Hokkaido, Japan from 1991-2008 (mostly in 1992). Females and larvae collected at various places in Hokkaido were reared indoors (temperature $15-30^{\circ} \mathrm{C}$, light for 16 hours per day or more). The specimens were caged together with a twig of their host plants, U. japonica or U. pumila, and the oviposition and feeding behaviour of individual specimens and the lengths of the development stages recorded. The overwintering eonymphs were kept outdoors in containers from October to March.

In each of 14 Romanian forest management units three $U$. glabra trees were examined and their individual infestation level assessed. This was done on 25.vii.2005 at Dulceşti, on 27.vi.2006 at Trifești, on 2.vii.2006 at Bălteni, Dobroslovești and Valea Mare, and on 5.vii.2006 at Adea. The elm trees were growing in mixed deciduous forests together with the dominant tree species Carpinus betulus, Fraxinus excelsior, Quercus robur and / or Robinia pseudoacacia. Each management unit is homogenous regarding site and stand conditions. The selected trees in each unit were of the same age, but positioned differently inside the stand. Individual age of the trees is known from examinations conducted in each unit every 10 years. Extent of defoliation was determined by visually estimating the relative leaf area consumed by $A$. leucopoda larvae. These outdoor measurements were re-assessed at random in the laboratory using a planimeter. Defoliation was determined for bottom, middle and top levels of a tree's crown, which may be at different heights depending on age and height of a particular tree. Samples from each level within the canopy of a tree comprised the leaves growing from 50 buds, which correspond to ca. 200 leaves per sample and level. Percentages of defoliation are expressed as average values for each group of three trees in a management unit, at each level in the crown and as an overall average for all three levels combined (Table 1).

Field observations on the occurrence and level of damage caused by A. leucopoda in Europe were conducted in Austria by E. Altenhofer in 2009, in Hungary by G. Csóka, C. Lestyán, J. Mikulás, J. Ódor, R. Pál and G. Vétek from 2003-2009, in Poland by T. Huflejt in 2003 and by M.W. Kozlowski in 2008-2009, in Romania by C. Ciornei, V. Lungu, D. Opariuc and V. Rusu in 2006, and in Slovakia by L. Roller in 2007-2009.

Taxonomic analysis was based on the examination of ca. 85 imagines and 50 larvae reared and collected in China, Japan and at European locations. Voucher specimens are deposited at: CSFU - Central Southern University of Forestry and Technology, Changsha, China; DEIC - Senckenberg Deutsches Entomologisches Institut, Müncheberg, Germany; HNHM - Hungarian Natural History Museum, Budapest, Hungary; IZSAS Institute of Zoology, Slovak Academy of Sciences, Bratislava, Slovakia; NSMT - National Museum of Nature and Science, Department of Zoology, Tokyo, Japan; UOPJ - Entomological Laboratory, Graduate School of Life and Environmental Sciences, Osaka Prefecture University, Osaka, Japan; ZMAS Zoological Institute of the Russian Academy of Sciences, St. Petersburg, Russia; and ZMPA - Museum and Institute of Zoology, Polish Academy of Sciences, Warszawa, Poland. Morphological terminology generally follows Goulet (1992), Huber \& Sharkey (1993) and Viitasaari (2002). The scutoscutellar furrow is the furrow between the lateral mesoscutellar lobes and the mesoscutellum. The terminology of surface structures is that of Harris (1979): rugose $=$ wrinkled, covered with ridges of various sizes and irregular orientation; scrobiculate $=$ covered with transverse, parallel ridges at subequal distances. The taxonomic analysis was conducted by S.M. Blank.

The distribution map (Fig. 8) was prepared from a draft map produced by Carto Fauna-Flora 1.2 (Barbier \& Rasmont, 1996). For light microscopic imaging of collection material (Figs 7, 9-11), stacks of digital photos were taken with a KYF-F75U camera (JVC) attached to a Leica Z6 APO zoom system. Composite images with an extended depth of field were created using the software CombineZ5 or alternatively AutoMontage 5.01 and subsequently processed with other graphic programs. The other images were taken with various standard cameras.

Even today, there is no agreement on the classification of elms. Extensive (introgressive) hybridization and artificial crossings have led to a confusing diversity of forms, which lack suitable characters for a convincing taxonomic differentiation (Mackenthun, 2009). To cope with this problem and to provide an unequivocal vocabulary for the present work, the species names here treated as valid are listed together with synonyms: $U$. davidiana Planch.; U. japonica Sarg. [synonym: U. davidiana var. japonica Sarg. (Praktijkonderzoek Plant en Omgeving, 2006)]; U. glabra Huds. [synonyms: U. campestris L. (Mackenthun, 2009), U. foliacea Gilib. (IPNI, 2009, as synonym of $U$. campestris)]; U. laciniata Mayr [invalid synonym: U. manchurica Nakai (Mackenthun, 2009)]; U. laevis Pall.; U. minor Mill. [synonym: U. carpinifolia Gleditsch (Mackenthun, 2009)]; U. pumila L. [synonym: U. turkestanica Regel (Mackenthun, 2009)]; U. pumila var. arborea Litv. 

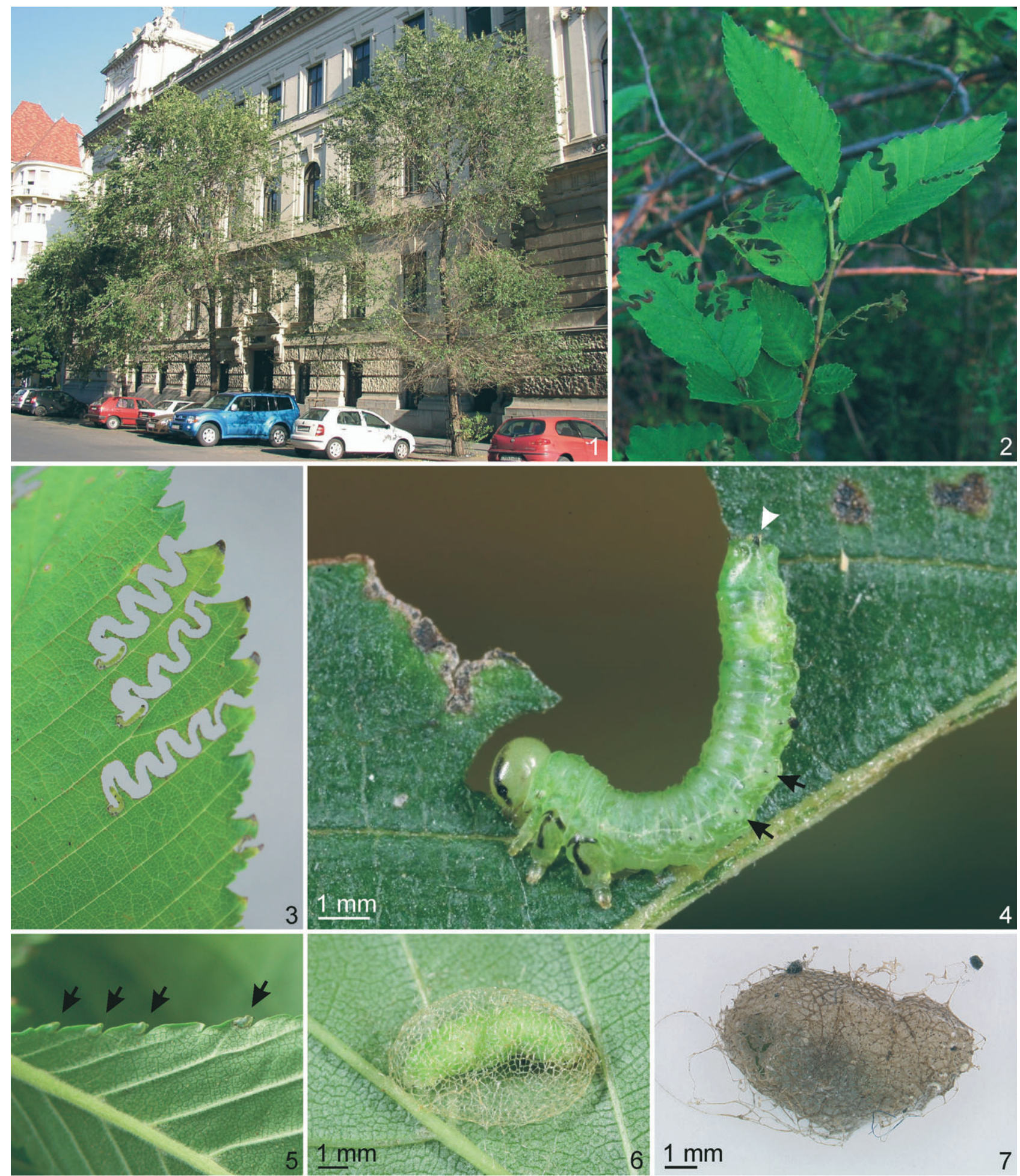

Figs 1-7. 1 - Defoliated Ulmus pumila var. arborea tree at the Museum of Ethnography in Budapest in 2008; 2 - leaves with the feeding tracks of old Aproceros leucopoda larvae; 3 - leaf with the zigzag feeding tracks of young A. leucopoda larvae; 4 - mature larva of $A$. leucopoda, black arrow indicates the lateral bulbous protrusions on middle abdominal tergum, white arrowhead indicates the lateral appendage on last tergum; 5 - eggs laid along leaf margin; 6 - loosely spun cocoon containing an eonymph attached to under-surface of a leaf; 7 - solid-walled cocoon.

\section{RESULTS}

\section{Bionomics of Aproceros leucopoda}

A mass occurrence of Aproceros leucopoda was observed at Shintoku, Hokkaido, Japan. Two 3-5 m high
Ulmus pumila trees were severely defoliated by larval feeding during 1991 to 1993 and then suffered dieback. Although $A$. leucopoda is common locally in Hokkaido, this is the first record of severe defoliation by this species in Japan. 
Imagines were found from mid-May to early September and late-instar larvae occurred from late June to late September. Phenological data on this sawfly revealed it has four generations per year. Imagines were active during mid- to late May, early to mid July, early August and early September. Late-instar larvae were observed in late June, late July, late August and late September.

Aproceros leucopoda is apparently exclusively parthenogenetic. No males are recorded. Under laboratory conditions, females produced females without copulation.

In the laboratory, the life-span of females varied from one to six days. Most individuals lived for two days and commenced oviposition soon after emergence. Females laid a total of 7-49 eggs singly into the tips of consecutive indentations around the edges of leaves (Fig. 5). Larvae hatched after $4-8$ days and fed on the leaves as in Figs 2-4 (photographs 2 and 4 taken in Hungary). Feeding traces of early stage larvae show a characteristic zigzag pattern (Fig. 3). Later an attacked leaf is completely consumed except for the thick middle vein. Larvae had six instars and completed development within 15-18 days. The eonymph made either a loosely spun cocoon with a net-like structure (Fig. 6) or a more compact, solidwalled cocoon with a grid of silk strands fixed to the surface (Fig. 7). In the field, loosely spun cocoons were found attached to the lower surface of elm leaves, rarely on twigs or the ground. Pupation in these cocoons occurred after 2-3 days and imagines emerged 4-7 days after the cocoons were produced. In this case, the total period from oviposition to imaginal emergence took 24-29 days. Solid-walled cocoons were found in the field in the litter or soil. These obviously correspond with cocoons produced by Chinese specimens, which $\mathrm{Wu}$ (2006) describes as double-walled with the inner wall solid. Larvae in solid-walled cocoons collected in Hokkaido in 1992 did not pupate even after about 3-7 weeks in the laboratory. Under natural conditions they would probably have overwintered. Three of four larvae collected on 17.viii.2008 from $U$. japonica at Hakodate, Kikyo, produced loosely spun cocoons from which imagines emerged on 25.viii.2008. The remaining larva made a solid-walled cocoon and the imago emerged after overwintering on 5.iv.2009. Overwintering individuals are produced continually from spring to autumn, because loose and solid cocoons were produced by larvae collected in early June, late July and late September.

In Hungary, A. leucopoda is on the wing earlier than in Hokkaido: imagines occur from mid April till early September. Late instar larvae are found from mid May.

\section{Larval host plants of Aproceros species}

Larvae or cocoons of Aproceros leucopoda were collected from Ulmus ?glabra, U. ?laevis and $U$. minor in Austria, and from U. minor, U. pumila and U. pumila var. arborea in Hungary. All observations in Romania were made on U. glabra. The possibility that some of these hosts may have been misidentified can not be excluded due to the considerable problems associated with identification of elm species (see Material and Methods). Nevertheless, the records reveal that in Europe A. leucopoda feeds on several native (U. glabra, U. ?laevis, U. minor) and cultivated species of elm (U. pumila including var. arborea).

During this study, larvae were collected on U. japonica and U. pumila in Japan (see also Naito, 2004). In the original description of A. leucopoda, Takeuchi (1939) notes that on Hokkaido "according to [the collector] Dr. H. Kôno, the larva of this species feeds on Manchurian elm." Most likely this record refers to U. pumila, which was introduced into Japan from northeastern China (Uehara, 1957; Tsujii et al., 1992). Wu (2006) interpreted Manchurian elm in this context as $U$. laciniata Mayr (= "U. manchurica"). Wu (2006) and Wu \& Xin (2006) also record "Siberian elm" (a common name for U. pumila), $U$. davidiana and an unidentified elm species from Gansu sheng, China.

Two A. pallidicornis (Mocsáry, 1909) specimens collected in Amurskaya oblast in the Russian Far East were reared from cocoons found on an elm (Zhelochovtsev \& Zinovjev, 1992; one male checked here, ZMAS). Three females of a possibly undescribed Aproceros species from Japan (Honshu, Karuizawa) bear a label "feed on Ulmus" (NSMT). Since cocoons and (parts of) elm leaves are preserved on the pins of these specimens, they undoubtedly were reared.

\section{Distribution of native and immigrant Aproceros leucopoda}

Aproceros leucopoda was described from Hokkaido, Japan by Takeuchi (1939). Additional material was collected on Hokkaido and Honshu, Japan (H. Hara, present data; Naito, 2004) and in Gansu, China (Wu, 2006; Wu \& Xin, 2006). Zhelochovtsev \& Zinovjev (1995) record $A$. leucopoda in the Far East of Russia but this record requires taxonomic confirmation. In Europe, the first specimens were collected in Hungary and Poland in 2003. The pattern of earliest records for single sites reveals neither a restricted region where the species was introduced nor a particular direction of the current spread (Fig. 8). Currently, there are the following records for Europe:

Austria. Vienna E, nature conservation area Lobau [ca $48.18^{\circ} \mathrm{N}, 16.50^{\circ} \mathrm{E}$ ], 5.vii.2009, defoliated young, $4 \mathrm{~m}$ high $U$. ? glabra with empty cocoons of first generation on leaves, ovipositing females, early instar larvae and zigzag feeding traces of second generation. Lower Austria: Hochstraß [ca $48.13^{\circ} \mathrm{N}$, $15.97^{\circ} \mathrm{E}$ ], 20.vii.2009, larvae on U. ?laevis; Traismauer [ca $\left.48.35^{\circ} \mathrm{N}, 15.73^{\circ} \mathrm{E}\right]$, gallery forest along the Danube, 11.vii.2009, larvae on U. ?glabra, U. ?laevis, U. minor, mostly in half-shady and humid places, comparatively abundant along forest road (3우 reared, DEIC); Neulengbach [ca $48.18^{\circ} \mathrm{N}, 15.98^{\circ} \mathrm{E}$ ], 20.vii.2009, larvae of early and mid instars on $U$. minor, 22.viii.2009, larvae and cocoons on $U$. minor (9ㅇ reared, DEIC); St. Pölten [ca $48.20^{\circ} \mathrm{N}, 15.63^{\circ} \mathrm{E}$ ], 20.vii.2009, larvae of early and mid stages on $U$. minor.

Hungary. Bács-Kiskun region: Baja $\left[46.183^{\circ} \mathrm{N}, 19.033^{\circ} \mathrm{E}\right.$, 8.vii.2006, larvae and pupae on Ulmus pumila; Kecskemét [46.900 $\left.{ }^{\circ} \mathrm{N}, 19.783^{\circ} \mathrm{E}\right]$, 5.vii.2008, pupae in cocoons among others on $U$. pumila var. arborea ( 2 reared, DEIC and HNHM), in 2009 peak of emergence of first generation on 12.iv., earliest larvae hatched between 14.-20.iv., cocoons recorded at beginning of May, earliest pupae on 11.v., imagines of second generation started emerging on 15.v.2009. Békés 


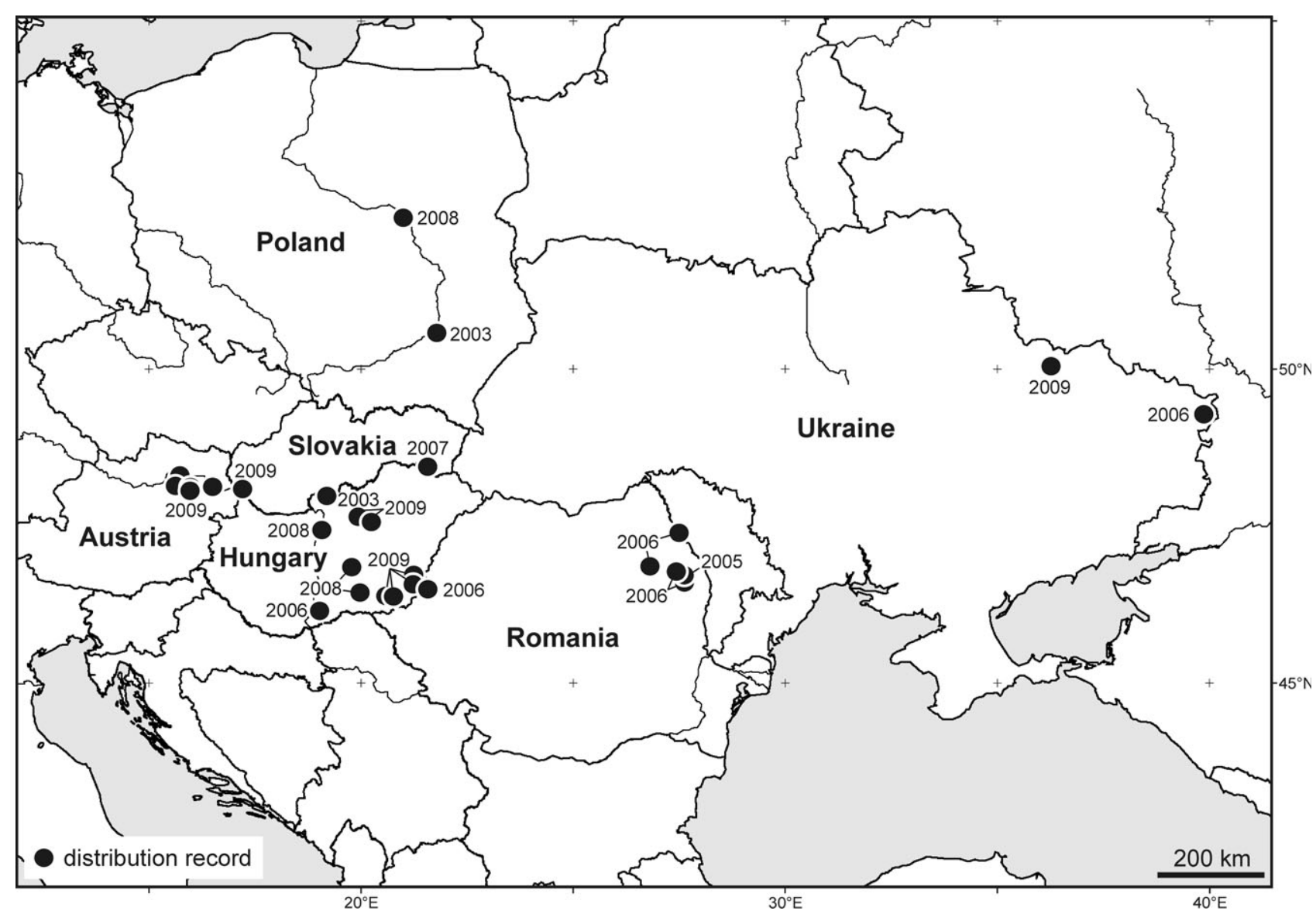

Fig. 8. Current distribution of Aproceros leucopoda in Europe. For each site, the year first recorded is indicated.

region: Békéssámson $\left[46.435^{\circ} \mathrm{N}, \quad 20.620^{\circ} \mathrm{E}\right], \quad 21 . v i i .2009$, feeding traces on $U$. pumila; Doboz $\left[46.783^{\circ} \mathrm{N}, 21.241^{\circ} \mathrm{E}\right]$, 22.vii.2009, feeding traces and cocoons on U. pumila; Gyula $\left[46.645^{\circ} \mathrm{N}, 21.243^{\circ} \mathrm{N}\right], 21 . v i i .2009$, feeding traces and cocoons on U. pumila; Tótkomlós [46.428 $\left.\mathrm{N}, 20.761^{\circ} \mathrm{E}\right], 21 . \mathrm{vii} .2009$, feeding traces and cocoons on $U$. pumila. Budapest $\left[47.500^{\circ} \mathrm{N}\right.$, $19.083^{\circ} \mathrm{E}$ ], 8.vii.2008, pupae in cocoons on $U$. pumila var. arborea (6 + reared, DEIC and HNHM). Csongrád region: Pusztaszer $\left[46.500^{\circ} \mathrm{N}, 19.983^{\circ} \mathrm{E}\right], 23 . v i .2008$, larvae and pupae on $U$. pumila and $U$. minor. Heves region: Alatka $\left[47.629^{\circ} \mathrm{N}\right.$, $20.248^{\circ} \mathrm{E}$ ], 7.ix.2009, feeding traces on U. pumila; Gyöngyös $\left[47.706^{\circ} \mathrm{N}, 19.938^{\circ} \mathrm{E}\right], 10.1 x .2009$, feeding traces on $U$. pumila. Nógrád region: Dejtár $\left[48.033^{\circ} \mathrm{N}, 19.183^{\circ} \mathrm{E}\right], 1 . v i i .2003$, larvae and pupae on $U$. minor.

Poland. Województwo (province) podkarpackie: Sandomierz Basin, Forest Inspectorate Nowa Dęba, Forest District Stale $\left[50.552^{\circ} \mathrm{N}, 21.787^{\circ} \mathrm{E}\right], 150 \mathrm{~m}$ altitude, 11.vi.2003, captured at the edge of forest dominated by Quercus robur and Carpinus betulus with admixture of $U$. ?laevis and other tree species (7우 ZMPA). Województwo (province) mazowieckie: Warszawa, Skarpa Ursynowska $\left[52.175^{\circ} \mathrm{N}, 21.051^{\circ} \mathrm{E}\right], 2008$ and 2009 , numerous larvae on young $U$. laevis growing at edge of mixed forest, at least two generations per year (Kozlowski 2009: photographs of "elm leaf enigma", accessed 16.ii.2010; M.W. Kozlowski, pers. comm.).

Romania (all observations made on U. glabra). Banat province: Adea $\left[46.550^{\circ} \mathrm{N}, 21.583^{\circ} \mathrm{E}\right], 90 \mathrm{~m}$ altitude, 5.vii.2006, feeding traces and cocoons. Moldova province: Bălteni $\left[46.667^{\circ} \mathrm{N}, 27.617^{\circ} \mathrm{E}\right], 120 \mathrm{~m}$ altitude, 2.vii.2006, larvae, pupae, imagines; Dobrosloveşti $\left[46.767^{\circ} \mathrm{N}, 27.600^{\circ} \mathrm{E}\right], 190 \mathrm{~m}$ altitude, 2.vii.2006, larvae, pupae, imagines; Dulceşti $\left[46.917^{\circ} \mathrm{N}\right.$, $26.817^{\circ} \mathrm{E}$ ], $210 \mathrm{~m}$ altitude, 25.vii.2005, feeding traces and cocoons; Trifesti $\left[47.450^{\circ} \mathrm{N}, 27.517^{\circ} \mathrm{E}\right], 40 \mathrm{~m}$ altitude, 2.vii.2006, larvae, pupae, imagines (numerous larvae and reared ${ }^{\circ}$, DEIC); Valea Mare $\left[46.817^{\circ} \mathrm{N}, 27.450^{\circ} \mathrm{E}\right], 140 \mathrm{~m}$ altitude, 27.vi.2006, larvae, pupae, imagines.

Slovakia. National Nature Reserve Súr [ca $48.13^{\circ} \mathrm{N}, 17.12^{\circ} \mathrm{E}$ ], $134 \mathrm{~m}$ altitude, 28.v.2009 (1 9 , IZSAS); Vihorlat Mts Vinné, hradný vrch [= castle hill; ca $\left.48.49^{\circ} \mathrm{N}, 21.57^{\circ} \mathrm{E}\right], 205 \mathrm{~m}$ altitude, swept from oak leaves (Quercus cerris or Q. robur) about $3 \mathrm{~m}$ above ground in wood-steppe like deciduous forest with dominant oaks, 24.v.2007 (1 9 , IZSAS).

Ukraine. Kharkiv Region, Kharkiv, Lesopark [ca $50.04^{\circ} \mathrm{N}$, $36.26^{\circ} \mathrm{E}$ ], 14.vi.2009, ㅇ (Mihajlovich, 2009: photos of "?Argidae", accessed 10.i.2010). Luhans'ka Region, Melovskiy District, Strel'tsovka, nature conservation area [ca $49.29^{\circ} \mathrm{N}$, 39.86리, 21.-31.viii.2006, leg. I.G. Severov, (2 9 , DEIC).

\section{Extent of damage and effect of pesticide application}

At the Romanian study sites, infested branches of Ulmus glabra were mainly situated in the upper canopy of forests. Top sections of the canopy of the 42 elms examined were more severely damaged than the middle or bottom sections (Table 1). The average defoliation of individual trees ranged from $74 \%$ to $98 \%$. Aproceros leucopoda showed no preference for host trees of a particular age. Tree age and average percentage defoliation are correlated at middle rank $(\mathrm{r}=0.595$; correlation coefficient after Pearson and Bravais), but the correlation coefficient $\rho$ for the population is not significant at the $5 \%$ level (confidence interval $-0.931<\rho<0,285$ includes 0$)$. 
TABLE 1. Percentage defoliation of trees by Aproceros leucopoda in 14 Romanian forest management units. Age in years and percentage defoliation rate (\% of leaf surface consumed by larvae) of three trees of Ulmus glabra in each unit, sorted by tree age. See Material and Methods for further information.

\begin{tabular}{|c|c|c|c|c|c|}
\hline \multirow{2}{*}{ Site name and management unit } & \multirow{2}{*}{$\begin{array}{l}\text { Tree age } \\
\text { (yrs) }\end{array}$} & \multicolumn{3}{|c|}{ Percentage defoliation of the canopy } & \multirow{2}{*}{ Average $\%$ defoliation } \\
\hline & & bottom & middle & top & \\
\hline Valea Mare, 51D & 12 & 85 & 91 & 95 & 90 \\
\hline Valea Mare, $52 \mathrm{~A}$ & 13 & 85 & 88 & 91 & 88 \\
\hline Valea Mare, 53E & 14 & 85 & 88 & 93 & 89 \\
\hline Trifeşti, 55/86 & 20 & 95 & 97 & 100 & 97 \\
\hline Trifeşti, 87 & 22 & 95 & 99 & 100 & 98 \\
\hline Adea, 2C & 25 & 75 & 78 & 85 & 79 \\
\hline Dulceşti, 32A & 25 & 90 & 93 & 95 & 93 \\
\hline Dobrosloveşti, 64 & 26 & 85 & 90 & 95 & 90 \\
\hline Valea Mare, 53A & 41 & 82 & 85 & 88 & 85 \\
\hline Adea, $4 \mathrm{~A}$ & 55 & 75 & 78 & 80 & 78 \\
\hline Adea, 4B & 55 & 78 & 82 & 85 & 82 \\
\hline Dulceşti, 32B & 55 & 89 & 92 & 95 & 92 \\
\hline Adea, $1 \mathrm{~A}$ & 60 & 70 & 74 & 77 & 74 \\
\hline Bălteni, 115A & 60 & 85 & 88 & 90 & 88 \\
\hline
\end{tabular}

In Hungary, damage was observed along roadsides, at the margins and in forests, and also in urban areas including inner cities. At Baja, Dejtár and Pusztaszer, individual elm trees (U. minor, U. pumila) suffered up to $100 \%$ defoliation but produced new leaves in the same year. In the centre of Budapest, all the elm trees examined (U. pumila var. arborea) were heavily infested (Fig. 1). These trees lost about $70 \%$ of their leaves. Attacked trees in the down town area, e.g., near the Parliament Building, are a significant aesthetic problem. Heavily defoliated trees did not seem to be dying. In Kecskemét, numerous elm trees, among them U. pumila var. arborea, were about $80 \%$ defoliated. A similar degree of defoliation was observed both in and outside the urban area. The damage was apparent from the beginning of July. The almost completely defoliated trees produced a second flush of leaves later in the season, at the same time as the imagines of the subsequent generation emerged. All the elm trees attacked in 2008 produced leaves in 2009, however, several branches had died. In spring 2009, 50-100\% of the leaves on these trees were completely consumed by larvae produced by the overwintering imagines.

In the urban area of Kecskemét, infested elms were sprayed with $0.04 \%$ Decis 2.5 EC (deltamethrin) and $0.075 \%$ Nomolt 15 SC (teflubenzuron) on 14.v.2009. This application was successful against larvae of the first generation, which were still present at that date. $\mathrm{Wu}$ (2006) reports that the application of a pesticide that killed more than $95 \%$ of first and second instar larvae.

\section{Species identification}

The native range of Aproceros is confined to eastern Asia, for which ten species are described (Taeger \& Blank, 2008). Identification keys for the species (e.g., Togashi, 1968; Wen \& Wei, 1998) are outdated and their use may produce ambiguous results. In an ongoing revision of Aproceros, the type material of described species was studied (S.M. Blank, unpubl.). Specimens collected in Europe are similar to the holotype of A. leucopoda
Takeuchi, 1939 preserved at UOPJ (Fig. 9). Points of morphological similarity include the pale scape and pedicel, the largely glabrous vertex, the bent and scrobiculate scutoscutellar furrow, the laterally steeply excised hypopygium and the uniformly subinfuscate wings. The holotype is of a specimen of one of the summer generations of A. leucopoda, which are generally paler and have shorter genae than the overwintering generation. Vikberg (2004) describes the seasonal dimorphism in head morphology and cocoon structure of species of Aprosthema Konow, 1899, a closely related genus of Sterictiphorinae: overwintering females have long genae and emerge from thick-walled cocoons, whereas females of the summer generation have short genae and emerge from thin-walled cocoons. We have observed a similar, seasonal dimorphism among Japanese A. leucopoda, but the differences in head morphology are less striking than in Aprosthema species. The specimens of the European A. leucopoda examined morphologically, have all belonged to the more or less brown summer generation with short genae. Cocoons obtained from Romania consistently were of the loosely spun type (Fig. 6). From a sample of larvae collected on 22.viii.2009 at Neulengbach, Austria, one eonymph produced a solid-walled cocoon and overwintered (Fig. 7), while imagines with short genae hatched from loosely spun cocoons in 2009.

Revision of the types and other material of Aproceros from East Asia reveal that some of the described taxa might be synonymous and other species remain to be described. The name leucopoda Takeuchi, 1939 is the second oldest available for Aproceros species. The only older valid name is A. pallidicornis (Mocsáry, 1909), which until recently was called $A$. umbricola Malaise, 1931 (Blank et al., 2009). This species is clearly distinguished from $A$. leucopoda by its setiferous vertex and the rugose surface of the scutoscutellar furrow. Thus, even if nomenclatural changes should occur during the course of the taxonomic revision, the application of the 
species name leucopoda to the European specimens will stand.

Imagines of $A$. leucopoda can be distinguished from other West Palaearctic Hymenoptera using the following key:

1 Antenna with 3 articles, article 3 very long (Fig. 9; Argidae).

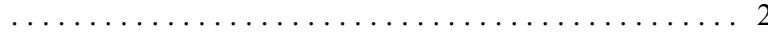
- Antenna with more articles. ......... other Hymenoptera

2 Radial cell $(\mathrm{R})$ on fore and hind wings open distally, veins R1 and Rs not meeting distally (Fig. 10). Transverse section of vein $\mathrm{Sc}+\mathrm{R}$ on fore wing absent (Fig. 10). Article 3 of antenna bifid in $\delta$. Hind tibia without preapical spine. (Sterictiphorinae)...................... 3

- Radial cell (R) on fore and hind wings closed distally, distally enclosed by veins R1 and Rs. Transverse section of vein $\mathrm{Sc}+\mathrm{R}$ on fore wing present. Article 3 of antenna clavate in $\delta$. Hind tibia usually with preapical spine, absent only in Kokujewia. (Arginae). . . . . . . . . . . . . . . ..... . Arge Schrank; Kokujewia Konow; Pseudarge Gussakovskij

3 Anal cell on hind wing absent, vein $2 \mathrm{~A}$ short, distally not joining vein $1 \mathrm{~A}$ (Fig. 10)................. 4

- Anal cell (A) on hind wing present, vein 2A long, enclosing basal anal cell (A) with vein 1A (Fig. 11). . . . . . . . . . . ............. Aprosthema Konow; Sterictiphora Billberg

4 On fore wing, sections of veins $M$ and Rs $+M$ joining vein $\mathrm{Sc}+\mathrm{R}$ within short distance (at most 0.2 longitudinal width of pterostigma) or at virtually same point (Fig. 10, see asterisk). Pronotum and mesonotum black or brown in ․ [o unknown. Additional characters: body black and brown to variable extent, at least head and mesoscutum black, earlier emerging generation supposedly darker; scape and pedicel brown, legs white; Fig. 9.] Distribution: East Asia (native), eastern and southeastern Europe (invasive). . . . . . . Aproceros leucopoda - On fore wing, sections of veins $\mathrm{M}$ and Rs $+\mathrm{M}$ joining vein $\mathrm{Sc}+\mathrm{R}$ at distance of ca 0.5 longitudinal width of pterostigma. Pronotum and mesonotum red in $q$. Distribution: Algeria, Tunisia..... . Pseudaprosthema Gussakovskij

Larvae of Pseudaprosthema and Pseudarge species have not yet been described morphologically. Pseudarge might possibly be recognized with help of the host plant Ermolenko (1975) noted Hulthemia berberifolia Dum. (Rosaceae) for Pseudarge rubicunda Gussakovskij, 1955. Among the other West Palaearctic Hymenoptera, A. leucopoda larvae can be identified as follows:

1 Prolegs present at least on middle abdominal segments, with several articles..................... 2

- Prolegs absent, if present then shaped as transverse bulges without discernible articles. . . . . . . . other Hymenoptera

2 Head capsule globular. Mouthparts orthognathous. External

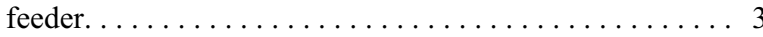

- Head capsule flattened. Mouthparts prognathous. Internal feeder. . . . . . . . . . . . . . . . . . . other Symphyta

3 Middle abdominal segments with 3 dorsal annulets. Thoracic legs with distinct pad adjacent to claw. Larvapods on abdominal segment 8 small or missing. (Argidae). . . . . 4 4

- Middle abdominal segments with 4-7 dorsal annulets. Thoracic legs without distinct pad adjacent to claw. Larvapods on abdominal segment 8 usually present, of similar size to those on preceding segments; if absent, then antenna with $4-5$ articles. . . . . . . . . . . . . . . other Symphyta
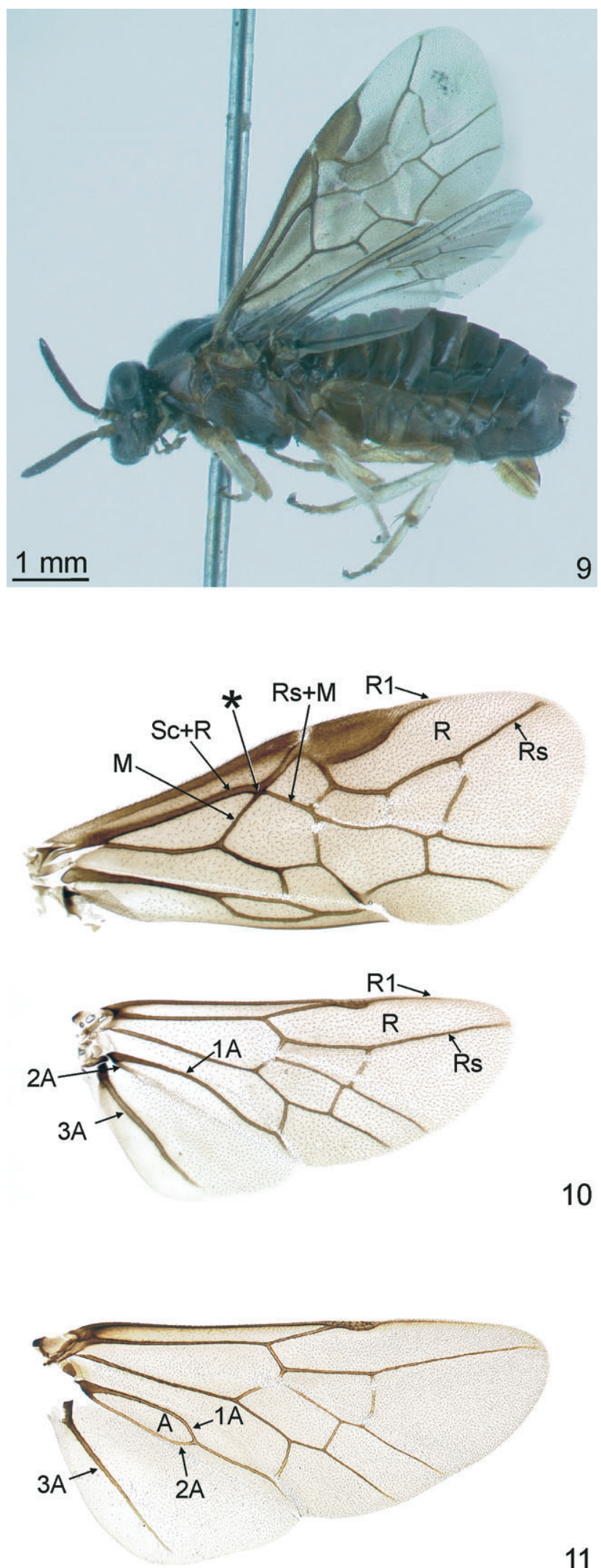

Figs 9-11. 9 - Aproceros leucopoda, holotype, ovipositor partly extended; 10 - fore and hind wing of A. leucopoda; $11-$ hind wing of Aprosthema sp. The wing veins, indicated by arrows with letters, and wing cells by only letters, are used in the identification key. 
Table 2. Duration of development (days) of multivoltine species of Palaearctic Argidae: duration of egg, larval feeding and the period between spinning the cocoon by the eonymph and imaginal emergence. The periods cited are those for the majority of the specimens from each population [e.g., a cocoon period of 20-25 days was recorded for 4\% of the Arge suspicax (Shinohara et al., 2008), 38 days for one of eight $A$. suzukii specimens (Shinohara \& Hara, 2008)]. The period spent in the cocoon is that recorded for non-diapausing generations.

\begin{tabular}{lcccl}
\hline \multirow{2}{*}{ Species } & \multicolumn{3}{c}{ Duration of development } & \\
\cline { 2 - 4 } & egg & larva & cocoon & \multirow{2}{*}{ Reference } \\
\hline Aproceros leucopoda Takeuchi, 1939 & $4-8$ & $15-18$ & $4-7$ & present work \\
Aprosthema melanurum (Klug, 1814) & $4-5$ & $10-11$ & $6-8$ & Vikberg (2004) \\
Arge captiva (F. Smith, 1874) & & $15-18$ & $19-24$ & Shinohara et al. (2009) \\
Arge indicura Shinohara \& Hara, 2009 & $8-12$ & $14-17$ & $11-20$ & Shinohara \& Hara (2009) \\
Arge nigripes (Retzius, 1783) & & ca. 20 & & Scheibelreiter (1973) \\
Arge ochropus (Gmelin, 1790) & & ca. 20 & & Scheibelreiter (1973) \\
Arge pagana (Panzer, 1797) & & ca. 20 & & Servadei (1934), Scheibelreiter (1973) \\
Arge pullata (Zaddach, 1859) & 10 & $21-33$ & $9-30$ & Takizawa (1962), Hara \& Shinohara (2008) \\
Arge suspicax Konow, 1908 & $6-7$ & $13-19$ & $9-15$ & Shinohara et al. (2008) \\
Arge suzukii (Matsumura, 1912) & 10 & $15-16$ & $13-21$ & Shinohara \& Hara (2008) \\
\hline
\end{tabular}

4 Supra-anal lobe with 1-2 pairs of appendages. Post-stigmal lobes of abdominal segments bulbously protruding or with sclerotized appendages (Fig. 4, see black arrows; Sterictiphorinae).......................... Supra-anal lobe without appendages. Post-stigmal lobe of abdominal segments unmodified. . . . . . . . Arge, Kokujewia

5 Thoracic legs 2-3 laterally with T-shaped, brown marks. [Additional characters: head capsule with lateral brown stripe crossing stemmata, post-stigmal lobes of abdominal terga 3-6 bulbously protruding with small central black sclerite, supraanal lobe with 1 pair of distal short brown appendages. Fig. 4.] Larval host plant: Ulmus spp......... ........................ Aproceros leucopoda

- Thoracic legs 2-3 laterally without T-shaped marks. Larval host plant: Fabaceae or Rosaceae. . . . . . . . . . . . . . ................... Aprosthema, Sterictiphora

\section{DISCUSSION}

The earliest known reliable records of Aproceros leucopoda for Europe only date back to 2003. Currently, the distribution of this species extends for more than 1,700 $\mathrm{km}$ from eastern Ukraine to Austria (Fig. 8). Possibly it arrived in Europe considerably earlier, but was not observed or recognized until recently. At least since the middle of the last decade, larvae have severely defoliated elm trees in Hungary and Romania. In 2006, A. leucopoda was also recorded as a pest in China, where the larvae damaged elms at Tianshui, Gansu sheng (Wu, 2006). Although infested trees were generally observed to grow new leaves in the same and following year, at least some branches of such trees may dieback. Data on longterm effects of the damage, e.g., an increased vulnerability to pathogens, is needed. In this context, the simultaneous attack of infested trees by the microfungi causing Dutch elm disease (DED) and reduction in leaf-mass caused by $A$. leucopoda should be monitored also for possible reinforcing effects.

Cocoons produced by the larvae are either attached to leaves or twigs or located in the litter or on the ground below infested trees (Wu, 2006; present data). Presumably, A. leucopoda was introduced from East Asia to Europe passively with elm plants used in horticulture or forestry. Transport with other merchandise, which in the country of origin was placed close to elm trees from which mature larvae descended for cocooning, is also possible. Passive dispersal along with traded material might be a major way in which this species rapidly extended its distribution over great distances within Europe, but active dispersal is also to be expected, since the imagines are strong flyers (Wu, 2006).

The climatic conditions on the northern Japanese island of Hokkaido, are similar to those in Central Europe, but the winters are usually colder, summers warmer and annual precipitation higher (mean temperature for Sapporo $-4.6^{\circ} \mathrm{C}$ in January, $21.7^{\circ} \mathrm{C}$ for August, annual mean $8.2^{\circ} \mathrm{C}$, mean annual precipitation $1134 \mathrm{~mm}$; World Climate Home, 2008). Currently, the distribution of A. leucopoda in Europe covers an area, which is on average warmer and dryer than Hokkaido (for Budapest as an example, mean temperature $-0.5^{\circ} \mathrm{C}$ in January, $21.5^{\circ} \mathrm{C}$ in July, annual mean $11.1^{\circ} \mathrm{C}$, annual precipitation $563 \mathrm{~mm}$; World Climate Home, 2008). The temperature and humidity conditions limiting the distribution of $A$. leucopoda remain to be studied in detail. However, based on climate data for Hokkaido it is likely this species will in the future spread into northern and south-western Europe, wherever elms grow.

Aproceros leucopoda larvae feed on several elm species. Oligophagy on elms may possibly be attributed to Aproceros as a whole, but few reliable data are available for individual species (Takeuchi, 1939; Zhelochovtsev \& Zinovjev, 1992; present data). Virtually all autochtonous or non-native elm species and their cultivars in Europe are likely to be potential hosts of $A$. leucopoda, although the actual vulnerability of individual species and forms needs to be studied. Larval monophagy and oligophagy are prevailing feeding strategies of sawflies and Argidae in particular (Vikberg, 2004; Hara \& Shinohara, 2008; Shinohara et al., 2008, 2009; Shinohara \& Hara, 2009). Closely related species of sawflies often infest plant species of a single genus or several closely related genera (Taeger et al., 1998). The results presented indicate that 
the larval host range of $A$. leucopoda is likely to be restricted to species of Ulmus. The record of an individual on oak in Slovakia, for example, is certainly the result of imaginal flight activity and does not reflect a trophic relationship.

Compared with other multivoltine species, A. leucopoda imagines that emerge in summer have one of the shortest life cycles among Palaearctic Argidae (Table 2). Their fast development is mainly a consequence of the brief period, of only 4-7 days, between cocoon spinning and imaginal emergence. This period is similarly short in Aprosthema melanurum, a closely related species within Sterictiphorinae, whereas it lasts 9 to 30 days in distantly related species of Arge, Arginae (Scheibelreiter, 1973; Vikberg, 2004; Hara \& Shinohara, 2008; Shinohara et al., 2008, 2009; Shinohara \& Hara, 2009). The rapid development observed in Aproceros and Aprosthema is associated with the production of a loosely spun cocoon attached to the host plant. This cocoon is apparently weak but produced more quickly than the solid-walled cocoon produced by individuals that overwinter in the ground. Imagines are likely to require stronger mandibular muscles to cut open a solid-walled than a loosely spun cocoon. Accordingly, imagines emerging in summer have shorter genae indicating weaker adductor muscles than those emerging in spring (Vikberg 2004; S.M. Blank, unpubl.). The evolution of a simplified cocoon is a precondition for the seasonal dimorphism in head morphology. Fast development and dimorphism in cocoon and head structure are putative apomorphies shared by Aproceros and Aprosthema, which reduce developmental costs and thus contribute to the proliferation of A. leucopoda.

The present results and those of $\mathrm{Wu}$ (2006) suggest that A. leucopoda is parthenogenetic unlike several other species of Aproceros (Malaise, 1931; Wei \& Nie, 1998; S.M. Blank, unpubl.). The majority of insects, including sawflies, introduced into new areas are parthenogenetic (Benson, 1962; Pschorn-Walcher, 1982; Mattson et al., 2007). Their ability to establish themselves after introduction is far greater than in bi-sexual species, as a female can give rise to a new colony without "wasting" time searching for a sexual partner. Most sawflies are univoltine. Multivoltinism is less common and frequently associated with outbreak species. The turnip sawfly Athalia rosae (Linné, 1758), for example, has up to 3 generations a year and imagines may be found as late as October in Central Europe (Sáringer, 1957; S.M. Blank \& A. Taeger, unpubl.). A. leucopoda can produce four generations per year (Wu, 2006; present data), which in combination with parthenogenetic reproduction and rapid development from egg to imago results in the production of numerous progeny.

Elms rarely form pure stands but usually grow intermixed with other tree species in forests (Mackenthun, 2009). For instance, there are only 4,300 ha of forest, in which elm is the predominant tree species, in Hungary. Typically, elm is associated with other broadleaved trees like ash (Fraxinus), hornbeam (Carpinus betulus) and oak
(Quercus). Similar mixed forests were present in the Romanian and Polish stands studied. Elms have some economic importance as they produce a valuable, heavy and strong wood that is used for special purposes in carpentry (Smalley \& Guries, 1993). In the Balkan, elms are used for afforestation of sites with extreme environmental conditions (e.g., dryness, alkaline soil). Some elm species and their cultivars are important ornamental trees or bushes planted along roadsides and in gardens and parks (Mackenthun, 2009). Particularly in urban areas, such as the centre of Budapest, the defoliation by A. leucopoda causes an aesthetic problem comparable to that caused by the horse chestnut leafminer, Cameraria ohridella, over the past decades.

In this study, it is noted that insecticides can be used to kill larvae of $A$. leucopoda. However, in view of the wide distribution of this species in Europe and the ability of its imagines to quickly re-invade a treated area, the local application of insecticides is unlikely to prove an effective way of controlling this pest. Blondelia nigripes (Fallén, 1810) (Diptera: Tachinidae), a widely distributed Palaearctic species, is the only parasitoid that has been reared from $A$. leucopoda (Shima, 1984, 2006). The distribution of $B$. nigripes within Europe includes the countries where $A$. leucopoda is currently recorded (Tschorsnig, 2007). This tachinid fly parasitizes larvae of numerous species belonging to three families of sawflies (Hymenoptera: Symphyta) and five families of moths (Lepidoptera). The wide host range of $B$. nigripes hinders an efficient control of $A$. leucopoda. The introduction of natural and specialized parasitoids in Europe accompanied by an extensive monitoring of the future spread of the pest and of the effect of the parasitoids on the abundance of this pest (Pschorn-Walcher, 1977) may lead to its sustainable control.

ACKNOWLEDGEMENTS. We are grateful to all the busy colleagues who supported this study by supplying us with field observations (see Material and Methods). Loan of types and additional material from collections was generously facilitated by S.A. Belokobylskij (St. Petersburg), S. Csősz and L. Zombori (Budapest), T. Hirowatari (Sakai), M. Kraus (Nürnberg), J. Ferrer (Stockholm), M.S. Saini (Patiala), A. Shinohara (Tokyo), D.R. Smith (Washington DC) and M. Wei (Changsha). W. Schedl (Innsbruck) donated two Ukrainian A. leucopoda specimens to the DEIC. A.D. Liston (Müncheberg), J.-L. Boevé (Brussels), M. Wei and two referees critically read this manuscript. This study was partly supported by a Grant-in-aid for Scientific Research No. 20580165 from the Japan Society for the Promotion of Science and a grant from the Slovak grant agency VEGA No. 2/0167/09.

\section{REFERENCES}

Barbier Y. \& Rasmont P. 1996: Carto Fauna-Flora (CFF) version 1.2. Université de Mons-Hainaut.

Benson R.B. 1962: Holarctic sawflies (Hymenoptera: Symphyta). Bull. Br. Mus. Nat. Hist. Entomol. 12: 379-409.

Blank S.M., Taeger A., Liston A.D., Smith D.R., Rasnitsyn A.P., Shinohara A., Heidemaa M. \& Vitasaari M. 2009: Studies toward a World Catalog of Symphyta (Insecta: Hymenoptera). Zootaxa 2254: 1-96. 
Brasier C. 1996: New horizons in Dutch elm disease control. Rep. Forest Res. 1996: 20-28.

Brown P.M.J., Adriaens T., Bathon H., Cuppen J., Goldarazena A., HäGg T., Kenis M., Klausnitzer B.E.M., Kováø I., Loomans A.J.M., Majerus M.E.N., Nedved O., Pedersen J., Rabitsch W., Roy H.E., Ternois V., Zakharov I.A. \& Roy D.B. 2008: Harmonia axyridis in Europe: spread and distribution of a non-native coccinellid. BioControl 53: 5-21.

Brummerstedt E., Kristensen A., Nielsen R. \& Bille-Hansen V. 1987: Death of a puppy after eating sawfly larvae. Case report. Dansk Veterinaertidsskr. 70: 758-760 [in Danish, English abstr.].

Ermolenko V.M. 1975: Tenthredinid sawflies. Argids. Diprionids. Tentredinids (Selandriinae, Dolerinae). Fauna of Ukraine. Vol. 10. Horntails and Sawflies. Part 3. Kiev, 374 pp. [in Ukrainian].

Goulet H. 1992: The genera and subgenera of the sawflies of Canada and Alaska: Hymenoptera: Symphyta. The Insects and Arachnids of Canada (Part 20). Agriculture Canada, Ottawa, Publication 1876, 235 pp.

Guichard S. \& Augustin S. 2002: Acute spread in France of an invasive pest, the horse chestnut leafminer Cameraria ohridella Deschka \& Dimic (Lep., Gracilariidae). Anz. Schädlingsk. 75: 145-149.

Hara H. \& Shinohara A. 2008: Taxonomy, distribution and life history of Betula-feeding sawfly, Arge pullata (Insecta, Hymenoptera, Argidae). Bull. Natn. Sci. Mus. (A, Zool.) 34: 141-155.

Harris R.A. 1979: A glossary of surface sculpturing. Occas. Pap. Entomol. 28: 1-31.

Holmes F.W. \& Heybroek H.M. 1990: Dutch Elm Disease The Early Papers: Selected Works of Seven Dutch Women Phytopathologists. American Phytopathology Society Press, St. Paul, MN, 154 pp.

Huber J.T. \& Sharkey M.J. 1993: Structure. In Goulet H. \& Huber J.T. (eds): Hymenoptera of the World: An Identification Guide to Families. Agriculture Canada, Ottawa, pp. 13-59.

IPNI 2009: The International Plant Names Index. http:// www.ipni.org/index.html.

Kannan R., Oelrichs P.B., Thamsborg S.M. \& Williams D.H. 1988: Identification of the octapeptide lophyrotomin in the European birch sawfly (Arge pullata). Toxicon 26: 224-226.

Kozlowski M.W. 2009: Elm leaf enigma. In HymIS forum. All about Bees and Wasps. http://www.forum.hymis.de

Mackenthun G. 2009: Handbuch der Ulmengewächse. http://www.ulmen-handbuch.de.

MALAISE R. 1931: Blattwespen aus Wladiwostok und anderen Teilen Ostasiens. Entomol. Tidskr. 52: 97-159.

Mattson W., Vanhanen H., Veteli T., Sivonen S. \& Niemelä P. 2007: Few immigrant phytophagous insects on woody plants in Europe: legacy of the European crucible? Biol. Invasions 9 : 957-974.

Minajlovich L.B. 2009: Argidae. In BugGallery v. 1.0. $\mathrm{http} / / /$ barry.fotopage.ru

Naito T. (ed.) 2004: Species Diversity of Sawflies in Hyogo Prefecture, Central Japan. Monograph of Nature and Human Activities 1. Hyogo, 85 pp. +10 pls.

Praktijkonderzoek Plant en Omgeving 2006: List of Names of Woody Plants and Perennials. $\mathrm{http}: / / \mathrm{www}$. internationalplantnames.com.

PSCHORN-WALChER H. 1977: Biological control of forest insects. Annu. Rev. Ecol. Syst. 22: 1-22.

Pschorn-Walcher H. 1982: Unterordnung Symphyta, Pflanzenwespen. In Schwenke W. (ed.): Die Forstschädlinge Europas.
Vol. 4. Paul Parey, Hamburg and Berlin, pp. 4-196 + 232-234.

SÁringer G. 1957: The turnip sawfly Athalia rosae L. (= colibri Christ. Hym. Tenthredinidae)] . Növenyterm. Kut. Intéz. Évk. 7: 125-183 [in Hungarian, Russian and German abstr.].

Scheibelreiter G.K. 1973: Die Tenthrediniden der Rose (Rosa spec.). Z. Angew. Entomol. 72: 225-259.

Servader A. 1934: Contributo alla conoscenza dei Tenthredinidi (Hymenoptera Symphyta) delle Rose. II. Arge pagana Panz. Boll. Lab. Entomol. R. Ist. Sup. Agr. Bologna 6: 179-208.

Shima H. 1984: Study on the tribe Blondeliini from Japan (Diptera, Tachinidae) V. The genera Blondelia RobineauDesvoidy and Compsilura Bouché. Kontyû 52: 540-552.

Shima H. 2006: A host-parasite catalog of Tachinidae (Diptera) of Japan. Makunagi, Acta Dipt. (Suppl. 2): 1-171.

Shinohara A. \& Hara H. 2008: Taxonomy, distribution and life history of Abelia-feeding sawfly, Arge suzukii (Hymenoptera, Argidae). Jap. J. Syst. Entomol. 14: 29-47.

Shinohara A. \& Hara H. 2009: Arge indicura n.sp. feeding on Potentilla and Sanguisorba (Insecta, Hymenoptera, Argidae) in Japan. Bull. Natn. Mus. Nat. Sci. (A, Zool.) 35: 55-71.

Shinohara A., Hara H. \& Saito T. 2008: Taxonomy, distribution and life history of Sanguisorba-feeding sawfly, Arge suspicax (Hymenoptera, Argidae). Jap. J. Syst. Entomol. 14: 265-282.

Shinohara A., Hara H. \& Kim J.W. 2009: The species-group of Arge captiva (Insecta, Hymenoptera, Argidae) in Japan. Bull. Natn. Mus. Nat. Sci. (A, Zool.) 35: 249-278.

Smalley E.B. \& GuRIEs R.P. 1993: Breeding elms for resistance to Dutch elm disease. Annu. Rev. Phytopath. 31: 325-352.

TAeger A. \& Blank S.M. 2008: ECatSym - Electronic World Catalog of Symphyta (Insecta, Hymenoptera). Program version 3.9, data version 34 (5.9.2008). http://dzmb1.biologie. uni-oldenburg.de/dei/ecatsym/ecatsym.php

Taeger A., Altenhofer E., Blank S.M., Jansen E., Kraus M., Pschorn-Walcher H. \& Ritzau C. 1998: Kommentare zur Biologie, Verbreitung und Gefährdung der Pflanzenwespen Deutschlands (Hymenoptera, Symphyta). In Taeger A. \& Blank S.M. (eds): Pflanzenwespen Deutschlands (Hymenoptera, Symphyta). Kommentierte Bestandsaufnahme. Goecke \& Evers, Keltern, pp. 49-135.

TAEger A., Blank S.M. \& Liston A.D. 2006: European sawflies (Hymenoptera: Symphyta) - a species checklist for the countries. In Blank S.M., Schmidt S. \& Taeger A. (eds): Recent Sawfly Research: Synthesis and Prospects. Goecke \& Evers, Keltern, pp. 399-504.

TAKeUCHI K. 1939: A systematic study on the suborder Symphyta (Hymenoptera) of the Japanese Empire (II). Tenthredo 2: 393-439.

TAKIZAWA Y. 1962: Notes on a Betula-feeding sawfly, Kanbaruri-churenji (new Japanese name) (Interim report). Trans. Jap. For. Soc. 72: 340-342 [in Japanese] [cited after Hara \& Shinohara, 2008].

Thalmann C., Freise J., Heitland W. \& Bacher S. 2003: Effects of defoliation by horse chestnut leafminer (Cameraria ohridella) on reproduction in Aesculus hippocastanum. Trees 17: $383-388$.

Thamsborg S.M., Jorgensen R.J. \& Brummerstedt E. 1987: Sawfly poisoning in sheep and goats. Vet. Rec. 121: 253-255.

Togashi I. 1968: Japanese sawflies of the subfamily Sterictiphorinae (Hymenoptera, Symphyta). Kontyû 36: 285-293.

Tschorsnig H.P. 2007: Tachinidae. In Fauna Europaea. Version 1.3. http://www.faunaeur.org.

TsujI T., Umezawa S. \& Sato K. 1992: Common Trees of Hokkaido. Hokkaido University Press, Sapporo, 320 pp. [in Japanese]. 
Uenara K. 1957: The Illustrations of Trees I. Ariake-shobou, Tokyo, 1300 pp. [in Japanese].

van Lenteren J.C., Babendreier D., Bigler F., Burgio G., HokKanen H., Kuske S., Loomans A., Menzler-Hokkanen I., van Risn P., Thomas M., Tommassini M. \& Zeng Q.Q. 2003: Environmental risk assessment of exotic natural enemies used in inundative biological control. BioControl 48: 3-38.

van Lenteren J.C., Loomans A.J.M., Babendreier D. \& Bigler F. 2008: Harmonia axyridis: an environmental risk assessment for Northwest Europe. BioControl 53: 37-54.

Vitasaari M. 2002: The Suborder Symphyta of the Hymenoptera. In Viitasaari M. (ed.): Sawflies (Hymenoptera, Symphyta) I. A Review of the Suborder, the Western Palaearctic taxa of Xyeloidea and Pamphilioidea. Vol. 1. Tremex Press, Helsinki, pp. 11-174.

ViKBerg V. 2004: Seasonal head dimorphism and taxonomy of some European species of Aprosthema (Hymenoptera: Symphyta: Argidae). Beitr. Entomol. 54: 107-125.

Wei M. \& Nie H. 1998: Hymenoptera: Pamphiliidae, Cimbicidae, Argidae, Diprionidae, Tenthredinidae, Cephidae. In Wu H. (ed.): Insects of Longwangshan Nature Reserve. China Forestry Publishing House, Beijing, pp. 344-391.
Wen J. \& Wei M. 1998: Taxonomical study on the genus Aproceros Malaise (Hymenoptera: Argidae) from China with descriptions of two new species. J. Guangxi Agric. Univ. 17: $57-60$.

World Climate Home 2008: Sapporo, Japan: Climate, Global Warming, and Daylight Charts and Data. http://www. climate-charts.com/.

Wu X.Y. 2006: Studies on the biology and control of Aproceros leucopoda. Plant Prot. (Beijing) 32: 98-100 [in Chinese].

WU X.Y. \& XIN H. 2006: A new recorded species of the genus Aproceros Malaise (Hymenoptera: Argidae) from China. Entomotaxonomia 28: 279-280 [in Chinese].

Zhelochovtsev A.N. \& Zinovjev A.G. 1992: Order Hymenoptera. Suborder Symphyta. In Chistyakov Yu.A. (ed.): Nasekomye Khinganskogo Zapovednika. Part 2. [Insects of Khinganskiy Reserve]. Dal'nauka, Vladivostok, pp. 199-221 [in Russian].

Zhelochovtsev A.N. \& Zinovjev A.G. 1995: A list of the sawflies and horntails (Hymenoptera, Symphyta) of the fauna of Russia and adjacent territories. Entomol. Obozr. 74: 395-415 [English translation: 1996, Entomol. Rev. 75: 58-80.].

Received December 22, 2009; revised and accepted March 11, 2010 